\title{
THE RELATIONSHIP OF ATTITUDES TOWARDS PEACE WITH ATTITUDES TOWARDS WAR, SOCIAL DOMINANCE ORIENTATION AND GENDER
}

\author{
Sultan OKUMUŞOĞLU ${ }^{1}$
}

\begin{abstract}
The aim of this study is investigation of the attitudes towards peace in relation with attitudes towards war, social dominance orientation and gender. Participants were 74 university students (42 women). Age range is 18-24. Attitudes Towards Peace and War Inventory (Bizumic et al., 2013) and Social Dominance Orientation Scale (Sidanius, Levin \& Pratto, 1996) were used. Results revealed that, attitudes towards peace, has negative relationship with attitudes towards war and social dominance orientation. Analysis also revealed that social dominance orientation has positive correlation with attitudes towards war. According to stepwise regression analysis attitudes towards war explain the $\% 31$ of the variance of attitudes towards peace. Social dominance orientation and attitudes towards war together explain \%35.6 of the variance of attitudes towards peace. Analysis revealed no statistically significant gender based or economic status based differences in terms of attitudes towards peace, attitudes towards war and social dominance orientation. Results pointed out that rise of social dominance orientation and attitudes favoring war are related with reduction in attitudes towards peace. Findings revealed that in order to construct really sustainable peace it is important to work for positive changes in terms of social dominance orientation and attitudes towards war. To be able to hope existence of sustainable peace in world's future, development of education campaigns to prevent enormous increase of social dominance orientations seems vitally important.
\end{abstract}

Keywords: Social dominance orientation, Structural violence, Direct violence, Discrimination, Attitudes towards peace, Attitudes towards war.

\footnotetext{
${ }^{1}$ Assist.Prof.Dr., European University of Lefke, Art \& Sciences Faculty, Psychology Department, ssehitoglu(at)eul.edu.tr

*This study have been presented at 19th National Psychology Congress at İzmir in 5-7 September 2016 as oral presentation and study's abstract took place in conference proceedings.
} 


\title{
BARIŞA YÖNELIK TUTUMLARIN SAVAŞA YÖNELIK TUTUMLAR, SOSYAL BASKINLIK YÖNELIMI VE CINSIYYETLE ILIŞKISi
}

\begin{abstract}
$\ddot{o z z}$
$\mathrm{Bu}$ çalışmada barışa yönelik tutumların savaşa yönelik tutumlar, sosyal baskınlık yönelimi ve cinsiyetle ilişkisinin araştırılması amaçlanmıştır. Katılımcılar 74 üniversite öğrencisidir (42 kadın). Yaş aralığı 18-24'tür. Barışa ve Savaşa Yönelik Tutumlar envanteri (Bizumic et al., 2013) ve Sosyal baskınlık Yönelimi ölçeği (Sidanius, Levin \& Pratto, 1996) kullanılmıştır. Sonuçlar barışa yönelik tutumların savaşa yönelik tutumlar ve sosyal baskınlık yönelimi ile negatif korelasyonunu ortaya koymuştur. Analizler aynı zamanda sosyal baskınlık yöneliminin savaşa yönelik tutumlarla pozitif ilişkisini göstermiştir. Aşamalı regresyon analizlerine göre savaşa yönelik tutumlar barışa yönelik tutumlar varyansının \%30,1'ini açıklamaktadır. Sosyal baskınlık yönelimi ve savaşa yönelik tutumlar birlikte barışa yönelik tutumlar varyansının \%33,8' ini açıklamaktadır. Analizlere göre kadınlarla erkekler arasında ve farklı ekonomik düzeyler arasında barışa ve savaşa yönelik tutumlar ile sosyal baskınlık yönelimleri açısından anlamlı fark saptanamamıştır. Sonuçlar yükselen sosyal baskınlık eğilimleri ile savaşa yönelik olumlu tutumların barışa ilişkin tutumlarda azalmayla ilişkisine işaret etmektedir. Bulgular sürdürülebilir barışın inşası için sosyal baskınlık yönelimi ve savaşa ilişkin olumlu tutumlarda pozitif değişiklikler elde edilmesi yönünde çalışılması gerekliliğine dikkat çekmektedir. Dünyanın geleceğinde sürdürülebilir bir barışın varlığını umabilmek için sosyal baskınlık yönelimlerinde görülen büyük artışı aşağıya çekebilecek eğitim kampanyalarının geliştirilmesinin hayati önemi olduğu görülmektedir.
\end{abstract}

Anahtar Kelimeler: Sosyal Baskınlık Yönelimi, Barışa Yönelik Tutumlar, Savaşa Yönelik Tutumlar, Yapısal Şiddet, Doğrudan Şiddet, Ayrımcılık.

Okumuşoğlu, Sultan. "The Relationship Of Attitudes Towards Peace With Attitudes Towards War, Social Dominance Orientation And Gender”. ulakbilge 5. 17 (2017): 1821-1833

Okumuşoğlu, S. (2017). The Relationship Of Attitudes Towards Peace With Attitudes Towards War, Social Dominance Orientation And Gender. ulakbilge, 5 (17), s.1821-1833. 


\section{Introduction}

The question about the sameness of peace with the non-existence of war is still important and continuing question. Different definitions of peace have something in common about the description of peace as positive and negative peace. According to this, non-existence of any active war can be defined as 'negative peace' and resolution of conflictive situations with non-violent means can be defined as 'positive peace' (Galtung, 1996; Opotow, Gerson \& Woodside, 2005). Every year violence is leading to indescribably difficult pains. Every year globally innumerable children and adults are injured or died as a result of violence (World Health Organization [WHO], 2010; Krug, Dahlberg, Mercy, Zwi \& Lozano, 2002). Visible direct violence which removes peace from the context is associated with lots of factors. Direct violence is related with historical, social and cultural factors. Direct violence is related with interactions of these mentioned destructible inputs which causes indescribably difficult pains (Christie, Tint, Wagner, \& Winter, 2008). Direct violence is output of these destructive inputs. On the other hand 'direct violence' is not the only type of violence that exists. Direct violence almost always is together with 'structural violence'. Despite the fact that 'structural violence' causing pains as difficult as pains caused by 'direct violence', it is a sneaky, hidden type of violence. 'Structural violence' is a kind of violence that is embedded in social structures and normalized. Therefore while creating pains for 'others', for members of 'outside groups' structural violence is almost invisible (Winter \& Leighton, 2001).

Any kind of discrimination which leads to negative experiences for disadvantaged 'others' is accepted as an example of 'structural violence'. Therefore any kind of discrimination is an obstacle in terms of sustainable peace which is not expectant for upcoming conflicts (Rosenthal, \& Johnston, 1989).

Social dominance theory, suggests that social dominance orientation is a predictor of prejudice, hence powerful predictor of discrimination towards 'outside groups', towards 'others' (Sidanius, Pratto, Laar, \& Levin, 2004). According to social dominance theory, development and maintenance of violence vicious cycle is related with sneaky establishment of 'structural violence' into social structures and also with social dominance tendencies which promotes 'direct violence' (Sidanius, Pratto, Laar, \& Levin, 2004).

Social dominance theory has a causal relationship with prejudice towards outer groups (Sibley et al., 2007) and with legitimatization of ideologies that objects policies that are beneficial for 'outer groups', for so called inferior groups (Sibley, \& Duckitt, 2009). 
According to System Justification Theory, superiority beliefs about 'inner group' make development and continuation of violence towards 'other' possible through legitimatization of discriminative 'structural violence' which leads to 'direct violence' at the end. This legitimatizations through superiority beliefs works as a mediating factor which reduces cognitive dissonance and enables individuals to be violent towards ‘outer groups' (Jost \& Banaji, 1994).

To be able to hope for sustainable peace, roots of violence in terms of structural, historical, social and cultural factors should not be ignored (Christie, 2006; Christie, Tint, Wagner \& Winter, 2008) and should be investigated.

War starts in people's cognitions (Cairns, \& Darby, 1998), therefore for improvement of peace efforts focusing on related attitudes is important. Hence investigations about related attitudes appear as an important necessity.

Under the light of related literature in this study investigation of the attitudes toward peace in relation with attitudes toward war, social dominance orientation and gender was planned. As a secondary aim the differences regarding attitudes towards peace, attitudes towards war, and social dominance orientation in terms of economic status levels will be inquired.

\section{Method}

\section{Participants}

100 participants were reached according to availability principle (snowball sampling) and when uncompleted scales were excluded analysis carried out with 74 participants. Participants are 74 university students from various universities (42 women, 32 men; \%56.8 female and \%43.2 male). Age range of participants is $18-24$ $(\bar{X}=20.32, S D=1.4)$. Ethical principles followed, participation was on voluntary basis and informed consent was taken from each participant.

\section{Tools of Data Collection}

Attitudes were measured through 'Attitudes towards Peace and War Inventory' and 'Social Dominance Orientation Scale'. Demographics as age, sex were handled through demographics questionnaire.

Attitudes towards peace and war inventory: It is a nine point likert type scale which has 16 items. It was developed by Bizumic et al. (2013) to measure 
individual's attitudes related with peace and war. According to analysis of Bizumic et al (2013) regarding the original scale, Cronbach's alpha for attitudes towards peace scale was informed as 0.83 and Cronbach's alpha for attitudes towards war scale was informed as 0.90 (Bizumic et al., 2013).

Turkish standardization of the scale was conducted by Güler (2014). In terms of standardized form of the inventory which intended to measure individual's attitudes towards peace and war in Turkish culture, Cronbach's alpha for attitudes towards peace scale was informed as 0.79 and Cronbach's alpha for attitudes towards war scale was informed as 0.85 . Test-re test reliability coefficient for Turkish form of the inventory was informed as 0.78 (Güler, 2014).

In the presented study Cronbach's alpha and split half reliability coefficients of attitudes towards peace scale was found as 0.86 and 0.71 consequently. On the other hand in terms of attitudes towards war scale, Cronbach's alpha was found as 0.73 and split half reliability coefficient was found as 0.78 .

Instead of calculating a total mean score for the whole inventory, mean scores for each factor were calculated separately as it was preferred and conducted in the Bizumic et al's (2013) study and Güler's study (2014). From this point of view attitudes towards peace scale and attitudes towards war scale were handled as two separate scales while planning and conducting the presented study.

Social dominance orientation scale: It was developed by Sidanius, Levin \& Pratto (1996). It is a 7 point likert type scale which measures supporting attitudes for superiority beliefs about 'inner group' and group based discrimination and inequity for 'outer groups' which conceptualized as 'inferior' groups through 16 items. Cronbach's alphas which informed by Sidanius and Pratto (1999) through researches which were conducted in 14 different counties for the scale were given as changing between 0.66 and 0.92 .

Turkish standardization was performed by Karaçanta (2002). The Cronbach's alpha, split half reliability and test-re test coefficients of the Turkish form were informed consequently as $0.85,0.79$ and 0.86 (Karaçanta, 2002).

In the presented study, Cronbach's alpha and split half reliability of social dominance orientation scale were found consequently as 0.82 and 0.68 . 
Demographic Questionnaire: Participants demographics as age, gender and economic status (1=Not good, 2=Middle, 3=Above middle, 4=Good, 5= Very good) were collected by this questionnaire.

\section{Statistical Analysis}

This research is conducted through handling of self-reported data for investigation of the attitudes toward peace in relation with attitudes toward war, social dominance orientation and gender. Self report inventories was used for data collection. Ethical principles was followed and data handled from volunteered participants through snowball sampling method, according to availability principle. SPSS 16 was used for statistical analysis. Corelation, regression, variance analysis were used to see relationships among variables. Level of significance was determined as $<.05$.

\section{Results \\ Correlations}

Correlation analysis (Pearson) were performed to see the relationship of attitudes toward peace with attitudes toward war, and social dominance orientation. Results revealed that, attitudes towards peace are negatively correlated with attitudes towards war $(\mathrm{r}=-.55, \mathrm{p}<.01)$ and social dominance orientation $(\mathrm{r}=-.44$, $\mathrm{p}<.01)$. Results also pointed out that social dominance orientation is positively correlated with attitudes towards war $(\mathrm{r}=.45, \mathrm{p}<.01)$ (see Table 1$)$.

According to this result an increase in terms of social dominance tendencies and attitudes favoring war is related with decrease in attitudes favoring peace. On the other hand, an increase in social dominance tendencies is related with an increase in terms of attitudes favoring war.

Table .1 Correlations Among Variables

\begin{tabular}{lccccc}
\hline Variables & Gender & ES & Peace & War & SD \\
\hline Gender & 1 & & & & \\
ES & -0.18 & 1 & & & \\
Peace & 0.14 & -0.07 & 1 & & \\
War & -0.02 & 0.01 & $-0.55^{*}$ & 1 & \\
SD & 0.06 & -0.06 & $-0.44^{*}$ & $0.45^{*}$ & 1 \\
\hline
\end{tabular}

$* p<0.001 \quad$ ES:Economic Status; Peace=Attitudes Towards Peace; War=Attitudes Towards War; $\mathrm{SD}=$ Social Dominance Orientation. 


\section{Regression Analysis}

According to Stepwise Regression Analysis \%31 of the variance of attitudes towards peace was explained by attitudes towards war. \%35.6 of the variance of attitudes towards peace was explained by social dominance orientation and attitudes favoring war together (see Table 2).

Table 2. Significant Predictors of Attitudes Towards Peace According to Stepwise Regression Analysis

\begin{tabular}{lcrcccc}
\hline & $\mathrm{R}$ & $\mathrm{R}^{2}$ & $\mathrm{~B}$ & Beta & Std. Error & $\mathrm{F}$ \\
\hline Predictors & & & & & & \\
ATWar & 0.557 & 0.311 & 65.678 & -0.557 & 0.077 & $32.465^{*}$ \\
SDO & 0.597 & 0.356 & 70.141 & -0.240 & 0.081 & $19.665^{*}$ \\
\hline
\end{tabular}

$* p<0.001$; Abbreviations: ATWar= Attitudes Towards War; SDO= Social Dominance Orientation. Variables: Attitudes Towards Peace, Gender, Economic Status, Attitudes Towards War, Social

Dominance Orientation (Excluded variables: Gender, Economic status).

\section{One Way Analysis of Variance (ANOVA) for Examination of Gender Based Differences}

Investigation of gender based differences in terms of variables of the study was performed through one way ANOVA. According to one-way ANOVA results no statistically significant difference was found between males and females in terms of attitudes towards peace $(\mathrm{F}(1,72)=1.639, \mathrm{P}>.05)$, attitudes favoring war $(\mathrm{F}(1,72)=0.051, \mathrm{p}>.05)$ and social dominance orientation $(\mathrm{F}(1,72)=0.270, \mathrm{p}>.05)$ (see Table 3).

Table 3. Results and Descriptives of ANOVA for Gender Based Differences

\begin{tabular}{lllrrrr}
\hline Variables & Group & $\mathbf{n}$ & $\overline{\mathbf{X}}$ & SD & $\mathbf{F}$ & $\mathbf{p}$ \\
\hline ATPeace & Female & 42 & 51.02 & 13.01 & 1.639 & 0.20 \\
& Male & 32 & 54.40 & 8.39 & & \\
\hline ATWar & Female & 42 & 30.26 & 15.33 & 0.051 & 0.82 \\
& Male & 32 & 29.50 & 13.06 & & \\
\hline SDO & Female & 42 & 37.95 & 12.86 & 0.270 & 0.60 \\
& Male & 32 & 39.78 & 17.42 & & \\
\hline
\end{tabular}

ATPeace $=$ Attitudes towards peace; ATWar=Attitudes towards war; SDO=Social dominance orientation 


\section{Kruskall Wallis Analysis for Examination of Economic Status Based Differences}

Investigation of self-reported economic status based differences in terms of variables of the study were performed through Kruskall Wallis; non parametric equivalent of one way ANOVA.

According to results, no statistically significant differences in terms of attitudes towards peace mean scores was found between different economic status levels, $\chi^{2}(\mathrm{sd}=11.3, \mathrm{n}=74)=6.83, \mathrm{p}>.05$.

No statistically significant difference in terms of attitudes towards war mean scores was found between different economic status levels $\chi^{2}(\mathrm{sd}=14.3$, $\mathrm{n}=74)=2.89, \mathrm{p}>.05$.

Also no statistically significant differences regarding social dominance orientation mean scores was found between different economic status levels $\chi^{2}(\mathrm{sd}=14.9, \mathrm{n}=74)=8.30, \mathrm{p}>.05$.

\section{Discussion}

This study was planned to investigate individual's attitudes towards peace in relation with attitudes towards war, social dominance orientation, and gender. Stepwise regression analysis revealed that attitudes towards war explain the \%31 of the variance of attitudes towards peace. Social dominance orientation and attitudes towards war together explain \%35.6 of the variance of attitudes towards peace. Correlations among variables revealed that attitudes towards peace are negatively correlated with attitudes towards war and social dominance orientation. It means that an increase in terms of attitudes towards peace is related with a decrease in terms of attitudes favoring war and social dominance orientation which is parallel with the findings of Bizumic et al. (2013). Besides, finding which reveals that attitudes towards war is positively associated with social dominance orientation is also parallel with the findings of Bizumic et al. (2013) and also with findings of Güler's study (2014).

Since social dominance orientation is linked to the need for myths to justify discrimination, injustice and inequity in favor of in-group (Levin et al., 2012), it is obvious that the reduction efforts targeting social dominance orientation are important for reduction of violence (Okumuşoğlu, 2017). According to Christie et al (2008) in order to be able to construct a sustainable peace in the future of the society, individual's social dominance tendencies and attitudes towards war should 
decrease, and the mentioned results of the presented study are parallel with these suggestions.

As mentioned in the method section of the presented study 'attitudes towards peace' and 'attitudes towards war' subscales were handled as two separate scales. Instead of calculating a total mean score for the whole 'attitudes towards peace and war' inventory, mean scores for each factor were calculated separately as it was preferred and conducted in the Güler's study (2014) and Bizumic et al's study (2013). Accepting the attitudes towards peace and attitudes towards war as two distinct constructs was also supported by other researchers (Van der Linden, N., Leys, C., Klein, O., \& Bouchat, P., 2017) and the findings of the presented study.

In literature (Eryllmaz, 2009) a significant difference was reported between males and females in terms of attitudes towards peace. In the presented study no significant difference was found between males and females in terms of attitudes towards peace. These conflicting findings can be related with usage of different samples and inventories in the mentioned study and the presented study. In Eryllmaz's study 4 point likert type scale with 5 items was used for measuring attitudes towards peace. On the other hand in the present study Bizumic et al.'s nine point likert type inventory with 16 items with 8 items for attitudes towards peace subscale was used. While Eryllmaz's (2009) participants were from general population the present study's participants were university students. Between the mentioned studies there is also a time period which should be kept in mind in terms of possibilities of changes which might impact gender based differences in terms of attitudes.

The finding which points out no statistically significant difference between males and females in terms of attitudes towards peace, war and social dominance orientation can also be related with the homogeneity in terms of mentioned attitudes as a result of having certain level of education. Finding is also parallel with the suggestions from literature (Eagly, Diekman, Johannesen-Schmidt, \& Koenig, 2004) which claims that when role based differences between males and females (disadvantaged differences like lower education etc.) are controlled, gender based differences in attitudes will lessen or even disappear. These explanations are also parallel with the seemingly contradictory finding of Okumuşoğlu's (2017) study which reveals gender differences regarding higher social dominance orientation for men which has a sample from different educational levels and also informs education as best predictor of social dominance tendencies. When it is thought that certain level of education could be related with elimination of gender based differences it can be accepted as an important finding which implies the importance of education regarding attitude change. Therefore it can be said that findings of this 
study points out the importance of education in terms of role based differences in attitudes and claims that education could be an important key to hope for a sustainable peace. Future researches regarding different education levels with bigger samples are proposed. Future researches regarding quato sampling for different socio-economic statu levels are also proposed since the groups in the current study composed for different self-reported economic levels seems insufficient to generalizability of related analysis.

Since this study is a cross-sectional one there could be some limitations that should be mentioned. As any other cros-sectional design it is not providing data about the possible changes in attitudes of participants by interacting some factors like age, social climate etc. Future studies are recommended to increase relevant data related with attitudes towards peace which can be helpful for efforts to construct a sustainable peace. Studies with bigger samples and with different inventories are proposed. Studies which include some other variables as world views, beliefs, political preferences, social backgrounds of participants are also proposed.

Starting by Jost and Banaji's (1994) conceptualization it can be seen that if 'structural violence' which could disguise itself in many forms as prejudice and discrimination could be reduced, legitimization of 'direct violence' could also be lessen. Reduction of this legitimatization through superiority beliefs which works as a mediating factor which reduces cognitive dissonance and enables individuals to be violent towards 'outer groups' hopefully will lessen the 'direct violence' acts. There could be a hope in terms of prevention of violence vicious cycle towards 'the other' through education.

Social dominance orientation has informed as having a causal relationship with prejudice towards outer groups (Sibley et al., 2007) and with legitimatization of ideologies that objects policies that are beneficial for so called inferior 'outer groups' (Sibley, \& Duckitt, 2009). Results of this study which reveals a positive correlation between social dominance orientation and attitudes favoring war is parallel with the mentioned claims.

It was emphasized in literature that to be able to construct a sustainable peace, individual's social dominance orientations and attitudes towards war must change in positive way, must lessen (Christie, Tint, Wagner, \& Winter, 2008; Okumuşoğlu, 2017). These suggestions are parallel with results of the presented study. As a conclusion, to be able to hope existence of sustainable peace in world's future, development of education campaigns to prevent enormous increase of social dominance orientations and attitudes favoring war seems vitally important. 


\section{REFERENCES}

Bizumic, B., Stubager, R., Mellon, S., Linden, N., Iyer, R., \& Jones, B. (2013). On the (in)compatibility of attitudes toward peace and war. Political Psychology, 34(5), 673-693.

Cairns, E., \& Darby, J. (1998). The conflict in Northern Ireland: Causes,consequences and controls. American Psychologist, 53, 754-760.

Christie, D.J. (2006). What is peace psychology the psychology of? Journal of Social Issues, 62(1), 1-17.

Christie, D.J., Tint, B.S.,Wagner, R.V., \& Winter,D.D. (2008). Peace psycholgy for a peacefull World. American psychologist, 540-552.

Eagly, A.H., Diekman, A.B., Johannesen-Schmidt, M.C., \& Koenig, A.M.(2004). Gender Gaps in Sociopolitical Attitudes: A Social Psychological Analysis. Journal of Personality and Social Psychology, 87(6), 796-816

Eryılmaz, A. (2009). Barışa yönelik tutumların özsaygı ve cinsiyet değişkenleriyle incelenmesi. Balıkesir Üniversitesi Sosyal Bilimler Enstitüsü Dergisi, 12(21), 23-31

Galtung, J. (1996). Peace by peaceful means: Peace and conflict, development and civilization. London: Sage Publications.

Güler, E. (2014). Barışa yönelik tutumlar: Dehşet yönetimi kuramı ve bazı sosyopolitik değişkenler açısından bir inceleme. Ankara Üniversitesi Sosyal bilimler Enstitüsü, Ankara.

Jost, J. T., \& Banaji, M. R. (1994). The role of stereotyping in system justification and the production of false consciousness. British Journal of Social Psychology, 33(1), 127. 
Karaçanta, H. (2002). Üniversite öğrencilerinin sosyal baskınlı yönelimi ve başka bazı değişkenler açısından karşılaştırılması. Yayınlanmamış doktora tezi, Ankara Üniversitesi Sosyal Bilimler Enstitüsü, Ankara.

Krug, E. G., Dahlberg, L. L., Mercy, J. A., Zwi, A. B., \& Lozano, R. (2002). World report on violence and health. Geneva: WHO Press.

Levin, S., Matthews, M., Guimond, S., Sidanius, J., Pratto, F., Kteily, N., Pitpitan, E.V. \& Dover, T. (2012). “Assimilation, Multiculturalism, and Colorblindness:Mediated and Moderated Relationships Between Social Dominance Orientation and Prejudice." Journal of Experimental Social Psychology,48(1), 207-212. doi:10.1016/ j.jesp. 2011. 06.019.

Van der Linden, N., Leys, C., Klein, O., \& Bouchat, P. (2017). Are attitudes toward peace and war the two sides of the same coin? Evidence to the contrary from a French validation of the Attitudes Toward Peace and War Scale. PLoSONE, 12(9), e0184001. http://doi.org/10.1371/journal.pone.0184001

Okumuşoğlu, S. (2017). Sosyal Baskınlık Yöneliminin Kişilik Özellikleriyle İlişkisi. Ulakbilge, 5 (12), 881-895.

Opotow, S., Gerson, J., \& Woodside, S. (2005). From moral exclusion to moral inclusion: Theory for teaching peace. Theory Into Practice, 44(4), 280-292.

Rosenthal, K., \& Johnson,P. (1989). Attitudes toward structural violence and war. Paper presented at the annual meeting of the Western Psychological Association and the Rock Mountain Psychological Association, Reno,NV.

Sibley, C., \& Duckitt, J. (2009). The ideological legitimation of the status quo: Longitudinal tests of a social dominance model. Political Psychology, 31(1), 109-137.

Sibley, C., Wilson, M., \& Duckitt, J. (2007). Antecedents of men's hostile and benevolent 
sexism: The dual roles of social dominance orientation and right-wing authoritarianism. Personality and Social Psychology Bulletin, 33(2), 160-172.

Sidanius, J., Levin, S., \& Pratto, F. (1996). In prejudice, discrimination and conflict. International Journal of Intercultural Relations, 20(3), 385-408. DOI:10.1016/ 014 7-1767(96)00025-9, Database: ScienceDirect.

Sidanius, J. \& Pratto, F. (1999). Social dominance theory: An intergroup theory of social hierarchy and oppression. Cambridge: Cambridge University Press.

Sidanius, J., Pratto, F., Van Laar, C., \& Levin. S. (2004). Social Dominance Theory: Its Agenda and Method. Political Psychology, 25(6), 845-880.

Winter, D.D., \& Leighton, D.C.(2001). "Section II Structural Violence" In Peace, Conflict, and Violence: Peace Psychology for the 21 st Century (ed. Christie, D. J., Wagner, R. V., \& Winter, D. A. Englewood Cliffs), New Jersey: Prentice-Hall.

World Health Organization (2010). Violence prevention the evidence: Series of briefings on violence prevention. Geneva: WHO Press. 